Leonardo Freitas Ribeiro

\title{
A JORNADA DO BOOM DA ANIMAÇÃO BRASILEIRA ATRAVÉS DAS VOZES DOS PROFISSIONAIS INTEGRADOS AO CAMPO DA ANIMAÇÃO E INDÚSTRIA DE ANIMAÇÃO \\ BRASILEIRA
}

Tese de Doutorado

Tese apresentada ao Programa de Pós-Graduação em Design da PUC-Rio como requisito parcial para obtenção do grau de Doutor em Design.

Orientador: Prof. Alberto Cipiniuk 


\section{Pontificia Universidade Catolica \\ DO RIO DE JANEIRO}

\section{Leonardo Freitas Ribeiro}

\section{A jornada do Boom da animação brasileira através das vozes dos profissionais integrados ao Campo da Animação e indústria de animação brasileira}

Tese apresentada ao Programa de Pós-Graduação em Design da PUC-Rio como requisito parcial para obtenção do grau de Doutor em Design. Aprovada pela Comissão Examinadora abaixo assinada.

Prof. Cristiano José Rodrigues Facom-UFJF

Profa . Irina Aragão Departamento de Artes \& Design - PUC-Rio

Prof. Marcelo Lacerda de Almeida IAD-UFJF

Prof. Amaury Fernandes da Silva Junior ECO-UFRJ

Profa. Monah Winograd Coordenadora Setorial do Centro de Teologia e Ciências Humanas - PUC-Rio

Rio de Janeiro, 26 de outubro de 2018 
Todos os direitos reservados. É proibida a reprodução total ou parcial do trabalho sem autorização da universidade, do autor e do orientador.

\section{Leonardo Freitas Ribeiro}

Graduou-se em Arquitetura e Urbanismo pela Universidade Federal de Juiz de Fora, especializado em Animação pela Pontifícia Universidade Católica do Rio de Janeiro e é Mestre em Design e Doutor em Design pela mesma instituição. Membro do Laboratório de Representação Sensível (LaRS), atua como animador independente e pesquisador/instrutor de animação. Foi pioneiro na produção de curtasmetragens de animação no interior de Minas Gerais, seus curtas de animação foram exibidos no Brasil e no exterior, agraciados com diversos prêmios.

Ficha Catalográfica

Ribeiro, Leonardo Freitas

A jornada do boom da animação brasileira através das vozes dos profissionais integrados ao campo da animação e indústria de animação brasileira / Leonardo Freitas Ribeiro ; orientador: Alberto Cipiniuk. -2018.

307 f. : il. ; $30 \mathrm{~cm}$

Tese (doutorado)-Pontifícia Universidade Católica do Rio de Janeiro, Departamento de Artes e Design, 2018.

Inclui bibliografia

1. Artes e Design - Teses. 2. Cinema de animação. 3. Cinema de ação ao vivo. 4. Indústria da animação. 5. Animação comercial. 6. Animação autoral. I. Cipiniuk, Alberto. II. Pontifícia Universidade Católica do Rio de Janeiro. Departamento de Artes e Design. III. Título. 


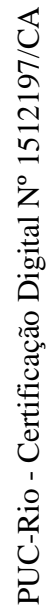

Para Ana Julia 


\section{Agradecimentos}

Ao meu orientador Prof. Dr. Alberto Cipiniuk, pela competência e dedicação na orientação desse trabalho, pelo escopo teórico cativante e provocativo que me apresentou e que continuarei a utilizar em futuras pesquisas.

Aos demais membros da Banca, Professores Amaury Fernandes da Silva Junior, ECOUFRJ, Cristiano Rodrigues, Facom-UFJF , Irina Aragão, PUC-Rio, Marcelo Lacerda de Almeida, IAD-UFJF e suplentes, Denise Portinari, PUC-Rio, Fabiana Heinrich, UFPel, por prontamente aceitarem o convite.

À minha mãe, Prof ${ }^{a}$. Maria Teresa de Assunção Freitas, que sempre foi um exemplo de pesquisadora e intelectual.

Ao meu pai, Jovino Santiago Ribeiro, assistente involuntário de pesquisa, pelos inúmeros recortes de jornal muito úteis à constituição desse trabalho.

À minha esposa Lene Tjørhom e à minha filha Ana Julia, pelo carinho, apoio e sobretudo pela compreensão durante os meses de ausência enquanto escrevia este trabalho.

Aos meus entrevistados, por me dedicarem um pouco de tempo e me responderem com honestidade e desprendimento minhas perguntas, constituindo assim, a espinha dorsal deste trabalho.

Aos estúdios que abriram suas portas às minhas visitas de campo. E a todos os animadores e demais agentes do Campo da Animação que contribuíram de uma forma ou outra para esta pesquisa. Destaco de modo especial Augusto Bicalho Roque, Diego Akel, Fábio Luiz Gonçalves Mendes, Jefferson AV, Jonas Brandão e Marta Machado.

Aos meus colegas de grupo de pesquisa, pelo companheirismo e trocas de ideias nestes últimos quatro anos.

Aos boêmios e amigos de Santa Teresa, dos quais sentirei muitas saudades.

O presente trabalho foi realizado com apoio da Coordenação de Aperfeiçoamento de Pessoal de Nível Superior - Brasil (CAPES) - Código de Financiamento 001. 


\section{Resumo}

Ribeiro, Leonardo Freitas; Cipiniuk, Alberto. A jornada do Boom da animação brasileira através das vozes dos profissionais integrados ao Campo da Animação e indústria de animação brasileira. Rio de Janeiro, 2018. 307p. Tese de Doutorado - Departamento de Artes \& Design, Pontifícia Universidade Católica do Rio de Janeiro.

O propósito deste trabalho é demonstrar como opera o mercado de animação nacional, dentro disso que se denomina o Boom da animação brasileira, incluído aos ditames do capitalismo flexível e da indústria "criativa". Para tal, nos distanciamos da noção de gênio criador, em proveito de uma visão da animação como um universo onde os saberes e procedimentos são coletivos. Inicialmente nos aprofundamos na definição disso que é animação, relacionado-a à hibridação dos meios de produção e as consequências da evolução das técnicas digitais em relação ao conhecimento e prática dos animadores. Em seguida, utilizamos farto material empírico, através de entrevistas com animadores das mais diversas posições dentro do Campo da Animação brasileira. Priorizando a voz do animador mediano, que luta anonimamente no mercado de trabalho. Acreditamos que assim, conseguimos retratar como opera a animação nacional, além do que é mostrado ou dito pelos agentes privilegiados do Campo da Animação. Revelando: i) a precarização do trabalho como prática comum entre os estúdios de animação no Brasil; ii) uma produção nacional voltada a atender às necessidades dos canais exibidores, seguindo suas convenções estilísticas, o que denominamos estilo internacional; iii) a fragilidade das empresas brasileiras produtoras de animação, dependentes de incentivos governamentais e com graves problemas financeiros e administrativos. Assim, passamos à limpo os mitos que regem a profissão de animador, mostrando como e com quais ferramentas trabalham os animadores brasileiros, como são recrutados, treinados e como são remunerados. Também discutimos os resultados práticos realizados por este arranjo produtivo (Boom).

\section{Palavras-chave}

Cinema de animação; cinema de ação ao vivo; indústria da animação; animação comercial; animação autoral; mercado de trabalho; Boom; Brasil. 


\section{Abstract}

Ribeiro, Leonardo Freitas; Cipiniuk, Alberto (Advisor). The journey of the Boom of the brazilian animation through the voices of the professionals integrated in the Field of Animation and brazilian animation industry. Rio de Janeiro, 2018. 307p. Doctoral Thesis - Departamento de Artes \& Design, Pontifícia Universidade Católica do Rio de Janeiro.

The purpose of this work is to demonstrate how the market of the national animation operates, in which one denominates the Boom of Brazilian animation, including the precepts of flexible capitalism and of the "creative" industry. To do so, we distance ourselves from the notion of the genius creator, to give preference to a view of animation as a universe where the skills and procedures are collective. Firstly, we will examine the definition of that which is animation, relating it to the hybridization of the means of production and the consequences of the evolution of digital techniques in relation to the knowledge and experience of the animators. Subsequently we utilize a vast amount of empirical material, through the interviews with animators of the more diverse positions within the Field of Brazilian Animation. Prioritizing the voice of the average animator, who struggles anonymously on the work market. We believe that in this way we'll manage to describe how the national animation operates, beyond what is shown and said by the privileged agents of the Field of Animation. Revealing: i) the job instability/insecurity as a common practice between the animation studios in Brazil; ii) a national production aimed at attending the needs of the exhibiting channels, following their stylistic conventions, which we call the international style; iii) the fragility of the Brazilian companies, producers of animation, which depend on governmental incentives and that has serious financial and administrative problems. In this way we put an end to the myths that dominate the profession of animation, showing which tools the Brazilian animators work with, how they are recruited, trained and how they are remunerated. We also discuss the practical results that a realized by this productive arrangement (Boom).

\section{Keywords}

Animation; live action; animation industry; commercial animation; experimental animation; job market; Boom; Brazil. 


\section{Sumário}

1. Introdução

2. Digressões necessárias

2.1. Afinal, o que é animação?

2.2. O animador como profissional em trabalho colaborativo e o mito 67 do artista genial

3. Animadores uni-vos!

3.1. The Boom

3.2. Treinamento: do atelier renascentista ao moderno estúdio de Animação

3.3. Economia criativa e animação no Brasil

3.4. Made in Brazil

3.5. A precarização do trabalho criativo na "indústria" de animação brasileira

4. Coda

Anexo I. Roteiros das entrevistas (tópicos-guia) 


\section{Lista de figuras}

Imagem 1 - Teatro Óptico 44

Imagem 2 - Anomalisa (2015) 49

Imagem 3 - Jasão e os Argonautas (1963) e 51

O espetacular Homem-Aranha (2012)

Imagem 5 - Waking Life (2001) 57

Imagem 6 - Valsa com Bashir (2008) 58

Imagem 7 - Retratos de Viagem (2012) 61

Imagem 8 - Cartum de autoria de Chuck Jones 63

Imagem 9 - Carlos Saldanha 69

Imagem 10 - Alexander Alexeieff e Claire Parker 85

Imagem 11 - Xuxinha e Guto contra os Monstros do 115

Espaço (2005)

Imagem 12 - Tromba Trem 120

Imagem 13 - Turma da Mônica em Uma Aventura no 125

Tempo (2007)

Imagem 14 - Câmera Oxberry

159

Imagem 15 - Gumball e Ivandoe 213

Imagem 16 - As trapalhadas de Flap Jack e 213

Irmão do Jorel

Imagem 17 - Moon Girl and Devil Dinosaur e 216

Meu Amigãozão

Imagem 18 - Greve nos estúdios Walt Disney 267

Imagem 19-Pearl (2016) 293 


\section{Lista de tabelas}

Tabela 1 - Quadro de entrevistados 
Se o petróleo foi a matéria-prima mais importante do século $X X$, as pessoas serão a matéria-prima mais importante do século XXI. Esta afirmação poderia conter um grande otimismo não fosse a constatação de que as pessoas já foram a matéria-prima mais importante no século XVIII e XIX através da escravatura.

\section{Eduardo Corte-Real}

Cada especialista tem um especialista equivalente e oposto.

Arthur C. Clarke 